Ювілейні дати

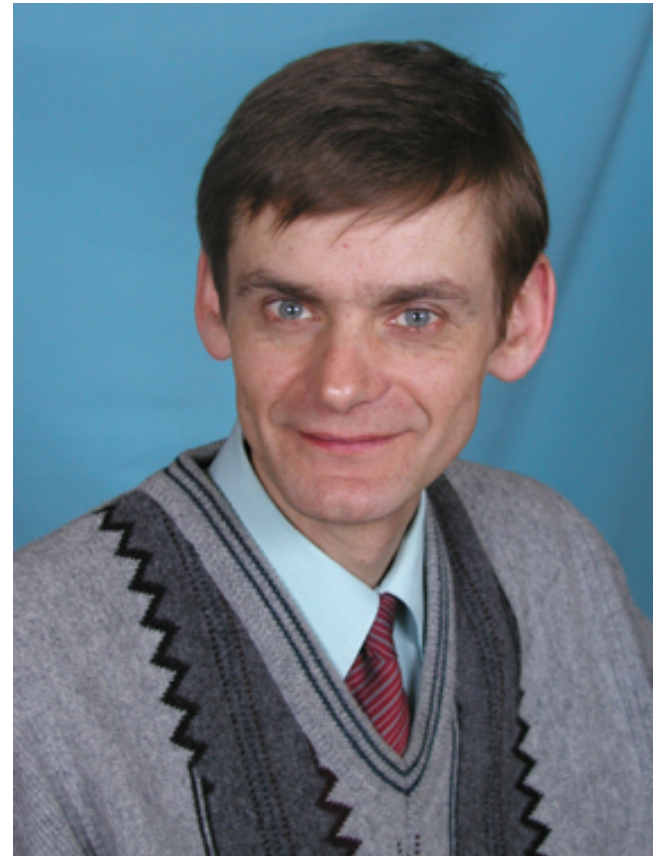

\title{
Півстоліття 3 юнацьким завзяттям (до 50-річчя професора Ігоря Юрійовича Костікова)
}

15 листопада цього року відомому в усьому світі вченому - ботаніку, фахівцю 3 альгології, флористики, систематики, філогенії, цитології та молекулярної таксономії водоростей, грунтової альгології, фіковірусології, завідувачу кафедри ботаніки біологічного факультету Київського національного університету імені Tараса Шевченка, доктору біологічних наук, професору Костікову Ігорю Юрійовичу виповнилось 50 років.

Народився Ігор Юрійович 15 листопада 1960 р. у м. Києві в сім’ї вченого-альголога Людмили Євгеніївни та інженера Юрія Павловича Костікових. Водоростями він почав цікавитись ще коли був школярем. Вирішальну роль у виборі життєвого шляху відіграло знайомство із видатним вченим, провідним фахівцем у галузі грунтової альгології, Емілією Адріанівною Штиною. Після закінчення середньої школи в 1977 р., Ігор Юрійович вступає на біологічний факультет Київського державного університету ім. Т. Г. Шевченка та обирає спеціалізацію нижчі рослини. Кафедру нижчих рослин на той час очолювала доктор біологічних наук, професор Надія Прохорівна Масюк, яка й стала науковим керівником Ігоря Юрійовича. У студентські роки Ігор Юрійович вивчає різні напрямки альгології, а по закінченні університету у 1982 р. вступає до аспірантури на кафедру нижчих рослин і починає працювати у зовсім новому для України напрямку - грунтовій альгології. Опанувати особливості дослідження грунтових водоростей Ігорю Юрійовичу допомагає всесвітньо відомий вчений, д-р біол. наук, проф. Штина Емілія Адріанівна у м. Кірові (Росія). Після успішного захисту кандидатської дисертації «Почвенные водоросли Правобережной Лесостепи УССР» (1989р.) Ігор Юрійович продовжує працювати на рідній кафедрі спершу на посаді асистента, потім доцента, а після захисту докторської дисертації «Грунтові водорості України» (2002 р.), очолює кафедру ботаніки і у 2004 р. отримує вчене звання професора.

Ігор Юрійович Костіков - визнаний фахівець світового рівня 3 грунтової альгології. Він провів перші дослідження грунтових водоростей Бельгійських Арденн та Аргентинських островів (Антарктика), разом зі своїми учнями встановив роль грунтових водоростей як одного 3 резервуарів вірусів вищих рослин (разом 3 В.Р. Бойко), ініціював в Україні початок робіт 3 оцінки якості води на основі діатомових індексів відповідно нормам СС (разом з А.А. Кривендою).

Він $є$ організатором та керівником однієї 3 найбільших на території СНГ колекції культур мікроводоростей (ACKU), в якій підтримується більше 900 штамів водоростей з різних таксономічних груп.

Ігор Юрійович виховав цілу плеяду учнів-альгологів, які успішно працюють у провідних наукових установах та освітніх закладах України та Західної Європи. Під його керівництвом підготовлено 2 кандидатські дисертації (B.P. Бойко, А.А. Кривенда,). Зараз він є науковим керівником ще трьох аспірантів та одного докторанта. 
Разом зі своїми учнями Ігор Юрійович підготував єдиний на сьогодні в Україні конспект флори грунтових водоростей, описав біля 40 нових для науки таксонів водоростей. Серед них роди Garhundacystis I. Kostikov \& L. Hoffmann, Sphaerococcomyxa I. Kostikov, T. Darienko, A. Lukesová, \& L. Hoffmann, Diplosphaeropsis I. Kostikov, T. Darienko, A. Lukesová \& L. Hoffmann, Korshikoviobispora I. Kostikov, T. Darienko, A. Lukesová \& L. Hoffmann, Palmococcus I. Kostikov, T. Darienko, A. Lukesová \& L. Hoffmann, Planktococcomyxa I. Kostikov, T. Darienko, A. Lukesová \& L. Hoffmann, Sphaerochlamydella I. Kostikov, T. Darienko, A. Lukesová \& L. Hoffmann, Sphaeroneocystis I. Kostikov, T. Darienko, A. Lukesová \& L. Hoffmann; види Chloromonas antrorum Kostikov, Chloromonas prokudinii Kostikov \& Demczenko, Chlamydomonas ucrainica Demchenko, Massalski, Kostikov \& Hoffmann, Coenochloris aquatica I. Kostikov, T. Darienko, A. Lukesová, \& L. Hoffmann, Garhundacystis spadensis I.Kostikov \& L.Hoffmann, Gloeobotrys echinulatus Kost. et Levanets, Nautococcus verrucosus I. Kostikov, Radiococcus piscinalis I. Kostikov, T. Darienko, A. Lukesová, \& L. Hoffmann, Radiococcus skujae I. Kostikov, T. Darienko, A. Lukesová, \& L. Hoffmann.

Ігор Юрійович - автор понад 150 публікацій, з яких 3 монографії, 11 статей у престижних закордонних журналах 3 високим імпакт-фактором (Environmental Microbiology, European Journal of Phycology, Systematics and Geography of Plants, Belgian Journal of Botany, Archiv fur Protistenkunde (Algological Studies), Journal of Virological Methods, Hydrobiologia), организатор першої міжнародної конференції з грунтової альгології "Algae in Terrestrial Ecosystems" (2005). Має творчі зв'язки з широким колом альгологів більш ніж з 20-ти країн, серед яких куратор колекції SAG Геттінгенського університету (Німеччина) д-р Т. Фрідл, професори А. Масальський (у-т Кельце, Польща), Л. Гоффманн, Л. Ектор (Люксембург), П. Крот, Е. Гросс (у-т Констанц, Німеччина), О. Гончаров (І-т біології ДСОНЦ РАН, Росія) та ін.

Ігор Юрійович - співавтор низки посібників 3 екології, ботаніки, які впроваджені в навчальний процес багатьох університетів України. Навчальний посібник «Ботаніка. Водорості та гриби», який вийшов під його редакцією у 2005 році, зробив революцію у викладанні вітчизняної ботаніки. Це видання подолало майже півстолітній «ботанічний застій», який уразив викладання систематики водоростей та грибів.

Він є керівником групи при Міністерстві освіти та науки України з розробки Стандартів вищої освіти за напрямком "Біологія", членом експертної групи країн СНГ зі складання Стандартів вищої школи. Його консультації щодо використання нормативів та стандартів вищої освіти допомогли багатьом біологічним кафедрам України впровадити нові сучасні спецкурси та оптимізувати викладання нормативних дисциплін професійної підготовки фахівців-біологів.

Професор І.Ю. Костіков $\epsilon$ заступником головного редактора журналу "Альгологія", членом редакційної ради Чорноморського ботанічного журналу.

Надзвичайно активний та ініціативний науковець, він налагодив міжнародне співробітництво між кафедрою ботаніки та науковими установами і лабораторіями Люксембургу, Бельгії, Франції, Німеччини та Польщі. Крім міжнародних зв’язків Ігор Юрійович активно гуртує навколо себе науковців України в різних галузях біології. Він є одним з організаторів щорічних комплексних експедицій на південь степової зони України, які проводяться вже 5-й рік поспіль. Вечорами можна без втоми годинами слухати пригоди та неймовірні історії, які траплялися з професором під час чисельних експедицій по теренах Європи, Азії тощо.

Ігор Юрійович $є$ головою Всеукраїнського турніру юних біологів, довгий час був головою журі Всеукраїнської олімпіади 3 біології. Його принциповість, впевненість, професіоналізм, чіткість та алгоритмічність дій захоплюють школярів біологією - однією з перспективних та найважливіших наук XXI століття. 
Крім наукових здобутків, Ігор Юрійович є натхненним лектором. Промови І.Ю. Костикова супроводжуються повною тишею - кожен із студентів із захватом усвідомлює кожне слово, сказане професором.

За значний внесок у науку Ігор Юрійович Костіков у 2009 р. був відзначений подякою президента України.

Відданість науці, організаторський талант, велика наукова ерудиція, здатність підтримати та розвивати будь-яку творчу ідею завжди вирізняють Ігоря Юрійовича як вченого та керівника.

Сьогодні ювіляр, як завжди, багато працює, сповнений оптимізму і нових творчих задумів. Ми щиро бажаємо шановному Ігорю Юрійовичу їх здійснення, а також нових наукових досягнень, звершень та відкриттів, цікавих і плідних подорожей, неперевершених лекцій та вдячних учнів, колег!!!

В.В. Джаган, П.О. Романенко, А.А. Кривенда, В.Р. Бойко, О.С. Ходосовиев, В.П. Полішук 